\title{
Brucella の抗酸性染色について
}

\author{
今 泉清 \\ 国立了防衛生研究所兽疫部 (部長 田嶋嘉雄) \\ [受付：5月 1 日 1954 -年]
}

\begin{abstract}
緒言
グラム㓌性菌はグラム陽性囷及び抗酸性菌と異り対比 染色が困㰙で単染色が常用され，彷つて特殊の形態のる のを除いては一般に少数の菌の検出は容易ではない。特 に Brucella に於ては宿主体内に括ける菌の形態が固型 培地に発育したそれに比して小さく，染色性も悪く，染 抹標本及び組織切片中の少数の菌の検出判定には相当の 熟練を必要とする。私共は種々の実験動物に拈ける Brucellosis を迫求するに際して菌対細胞の関係を重視し, 之が解決の一手段として染色法の改善に努力をしてきた のであるが, 今回本菌の抗酸性染色について良好な結果 を得たので報告する。
\end{abstract}

\section{染色方法}

1. 材料作製 新鮮臓器の塗抹又はスタンプ標本を作 り宔溫で自然乾燥する。

2. 固定 クロ、ホルム固定（局方ク口、ホルムをピ ヘットでスライド上に滴下)。

3. アニリンフクシンで 30 分以上染色（室溫）。

4. 水洗。

5. 1500 倍稀橎䀧酸水で脱色分別 (フクシンの桃色が 加与かに残る程度。落し過ぎない様に注意する)。

6. 水洗。

7.メチレンブルーで後染色。

\section{試 轱}

アニリンフクシン: 蒸溜水約 $10 \mathrm{cc}$ にアニリン数滴を 混入, 強く振浻し濾過する。この濾液 10 に対し, $0.1 〜$ $0.3 \%$ 塩基性フクシン水溶液 1 を混合。アニリンフクシ ンは明るい桃色を呈し，か寸かに混濁の感がある。 醋酸水 : 水酳酸を蒸溜水で 1500 倍に稀翻したもの。

$$
\text { メチレンブルー：細菌単染色用。 }
$$$$
\text { 染色所見 }
$$

核，原形質乞の他 Brucella 以外は総てメチレンブル 一の青色をとり, Brucella は蘚紅色に染る。白血球や 単球の中の菌の状態は極めて蘚明で, 結核菌の抗轾性染 色と比較して㸓らない。

\section{考按}

Brucella が弱いながらも抗酸性，抗てルコール性で あることは既に CASTANEDA1) の指摘したところである 最近 $\left.\mathrm{K} \phi_{\mathrm{ST}^{\mathrm{T}} \mathrm{ER}}{ }^{2}\right)$ 法としてサフラニンと $0.1 \%$ 硫酸水を使 朋する方法が発表されているが，追試の結果原著に記載 している様な良好な結果は得られなかつた。私どすの方 法はその装作の容易なることは勿論鮮明度に心いても決 して他の染色法に劣るすのでないが，更に組織切片中の 菌の検出にも応用が出来る。然して Brucellosisに扎い ては菌対宿主の関係は複雑を極め, 宿主体内に出ける囷 の形態, 染色性も感染の各段階に応じていういらに変化 することが察知される。彷つて本法による Brucella の 形態，染色性が常に一定して同一の結果を辧らすもので はないことを理解する必要があろう。

最後に御指尊, 御校閱を賜つた田嶋部長に深謝する。

$$
\text { 文献 }
$$

1) Castaneda, M. R.: Brucellosis, Ann. Rev. Microb., IV. 331 342, 1950.

2) World Health Org. Techn. Rep. Ser., No. 37 , 27, 1951.

IMAIZUMI Kiyoshi.: Acid-fast staining for Brucella. Veterinary Division, National Institute of Health of Japan. - Jap. J. of Bact., 9 (9), 739, 1954 